UDC 338.24:631

DOI: https://doi.org/10.32782/2413-9971/2020-34-19

Kravchenko Mykola

Candidate of Economic Sciences, Associate Professor, Senior Lecturer at the Department of Accounting, Taxation and Management of Financial and Economic Security

Dnipro State Agrarian and Economic University

Izhboldina Olena

Candidate of Agricultural Sciences, Associate Professor,

Senior Lecturer at the Department

of Livestock Production Technologies

Dnipro State Agrarian and Economic University

Karamushka Oleksandr

Candidate of Economic Sciences, Associate Professor,

Senior Lecturer at the Department

of Information Systems and Technologies

Dnipro State Agrarian and Economic University

Кравченко М. В. кандидат економічних наук, доцент, дочент кафедри обліку, оподаткування та управління фінансово-економічною безпекою Дніпровського державного аграрно-економічного університету

Іжболдіна О. О.

кандидат сільськогосподарських наук, доцент, доцент кафедри технології виробництва продукції тваринництва Дніпровського державного аграрно-економічного університету

Карамушка О. М.

кандидат економічних наук, дочент,

дочент кафедри інформаційних систем і технологій

Дніпровського державного аграрно-економічного університету

\title{
THE ORGANIZATIONAL AND ECONOMIC MEASURES TO IMPROVE THE LEVEL OF MANAGEMENT OF ECONOMIC STABILITY AND EFFICIENCY OF ORGANIC FARMS IN THE AGRICULTURAL SECTOR
}

\begin{abstract}
Summary. In the articles there are highlighted theoretical principles of organization of economic measures in relation to the increase of level of management of economic stability and efficiency of enterprises of organic beekeeping in the agricultural sector. The organizational mechanism of cooperation is formed for "production-processing" line with the selection of three types of model enterprises. The association of beekeeping enterprises based on cooperation and the integrated systems in the direction of creating highly mechanized large apiaries is justified. The research of beekeeping enterprises productive forces should be done in order to achieve efficient use of objects and means of labour. This effect is due to the cognition of objective and subjective laws of development of productive forces, laws and principles of their functioning. The productive forces of beekeeping enterprises are in constant motion, changing its quality status and influence the level of economic stability of individual enterprise. This should be taken into account while their research and justification of improvement directions.
\end{abstract}

Key words: economic stability, enterprises of beekeeping, model enterprises, integrated systems, agricultural sector.

Problem outline. Beekeeping enterprises play an important role in ensuring food security of the country, the development of which affect the capacity of the domestic food market and adequacy indicators of food consumption by the population of country. Among the foodstuff, one of the important places belongs to bee products. Besides beekeeping enterprises supply raw materials for industrial production and cosmetic industries. Economic stability influences on the formation of beekeeping enterprises competitiveness, which depends on the management efficiency, financial resources availability, the amount and form of investments, creating production capacity based on innovations, management features.

Lack of system and fragmentation of revenue in production modernization, low investment activity, lack of integrated application of innovative technologies, imperfect economic mechanism of production management and interbranch relations and economic relations with processors and trading companies, lack of state support prevent the ensuring of beekeeping enterprises competitive development.

However, questions of systematic approach to understanding competitiveness as a complex economic category, features of beekeeping enterprises competitiveness, and effective ways of its insurance remain insufficiently studied. It necessitated the given study.

Recent research and publications analysis. The questions of agricultural enterprises competitiveness are considered in the works of a great number of Ukrainian and foreign scientists: I. Ansoff, V. Andriichuk, V. Aranciy, A. Arefieva, A. Babenko, A. Bellou, O. Berezin, I. Blank,B. Borisov, S. Vasylchak, I. Vinichenko, V. Vitlinsky, P. Haidutsky, Yu. Hubenya, O. Gudz, M. Demyanenko, M. Koretsky, N. Lobov, M. Malik, P. Makarenko, L. Melnyk, V. Mesel- 
Veselyak, V.Plaksiyenko, S.Pokropyvny,P. Sabluk, G.Savitska, O. Ulianchenko, A. Tsyhanyuk, A. Chupisa, V. Yurchishin and others.

Theoretical and practical bases of beekeeping rational management were studied by L. Bondarchuk, V. Zharov, V. Korzh, A. Lewandowska, V. Polishchuk, H. Pryimak, A. Cherkasov and others. Market research of beekeeping and the economic efficiency of production were covered in the works by S.Buhera, A. Bukreiev, O. Khristenko, S.A. Chekhov, O.M. Yatsenko and others.

Summary of the economic thought achievements shows that, despite the significant scientific contributions on issues of beekeeping enterprises competitiveness, large range of issues remain unresolved, in particular related to the deepening of the theoretical and methodological principles of beekeeping enterprises competitiveness.

The purpose of the article is to develop and justify theoretical, methodological and institutional framework for ensuring the beekeeping enterprises competitiveness.

Task outline:

- to clarify the conceptual framework of the research problems, including interpretation of the essence of the category of "competitiveness" of the enterprise;

to improve methodological approaches for the management of beekeeping enterprise competitiveness;

- to justify the organizational and economic measures implementing competitive strategies of beekeeping enterprises;

- to develop organizational and economic measures to improve the competitiveness of beekeeping enterprises.

Object of research is the process of management and ensuring competitiveness of beekeeping enterprises.

Subject of research is a set of theoretical, methodological and practical aspects of beekeeping enterprise competitiveness.

The main material of research. Ukraine is among the countries with developed bee production. This development is contributed by proper climatic conditions of the country, large areas of melliferous grounds and traditions of population to maintain the bees. These factors have provided high-quality reception of bee products, which is a prerequisite for the development of beekeeping enterprises, domestic and foreign agricultural markets.

As a result of organizational and structural changes, there is a negative trend in recent years in the beekeeping enterprises, as in many other agricultural enterprises. The number of bee colonies is reducing and their productivity is also reducing. Despite this situation, Ukraine is among the five leading countries that have developed production of bee products. Beekeeping enterprises activities play an important role in the economy of our country and ensure the production of honey, wax, royal jelly, propolis, apitoxin, pollen, pollination of entomophile crops.
However, in a volatile economic situation on the international and national markets, the growing demands for accelerated development of adequate national agricultural market, which is able to provide the balance of supply and demand, increase the profitability of beekeeping enterprises, accelerate development of rural areas and improve the goodness of the population. Production expansion of beekeeping enterprises products by the farmers can become a stabilizer in an unstable economic situation.

Transformation and development of market economy intensified structural reforms in the field of beekeeping, due to changes in organizational and legal forms of ownership, size and structure of enterprises, supply and demand, under the social division of labor.

Regarding the situation on the domestic market of beekeeping production, it is possible to say that it depends primarily on external trends. The global economic crisis significantly unbalanced this market, but it remains one of the most dynamic and globalized markets nowadays. There are more than $50 \mathrm{mln}$. colonies in the world, the number of entities engaged in beekeeping is about $7 \mathrm{mln}$. The largest number of bee colonies located in China (15\%), Russia (7\%), Turkey (6\%), Ukraine (6\%), the USA (5.5\%), Poland and Mexico (5\%). World production of honey is $1.5 \mathrm{mln}$. tons and exports -400 ths. tons annually. The leading world producers of honey are China, Argentina, Turkey, Ukraine, and the USA. Bee products market has a number of features, and in recent years there is active market redistribution between the major producers. Only a few countries are absolutely secured in its own beekeeping production: China, Canada, Ukraine, Russia, and Poland. Honey production in China reached 200 ths. tons, in the USA - 100 ths. tons, Mexico - over 50 ths. tons, Russia - about 50 ths. tons. Ukraine takes the 4th place in the world by total production of honey, the average is 75 ths. tons. Ukraine, among the European countries, takes the first place according to the relevant indicator, but only $6 \%$ of domestic honey is exported. This sector employs about 700 ths. people, which is $1.5 \%$ of the population. Country is among the five leading producers of honey in terms of consumption of this product per capita and gross output (Table 1).

In developed countries it is consumed about $1.5 \mathrm{~kg}$ of honey on average per person per year, while in developing countries - only a few tens of grams [2].

One of the main sources of financing of beekeeping enterprises in many countries is honey export earnings. The situation is quite different in Ukraine, especially when analysing the volume of honey production in Soviet times and the period of independence.

Taking into account the specificity of agricultural production, particularly bee production and implementation of complex interrelated agricultural activities in the aggregate: demand analysis, production of a certain technology,

World consumption of honey, 2015

Table 1

\begin{tabular}{|l|c|c|c|c|}
\hline \multicolumn{1}{|c|}{ Country } & $\begin{array}{c}\text { Production of honey, } \\
\text { ths. tons }\end{array}$ & $\begin{array}{c}\text { Quantity of bee colonies, } \\
\text { mln. pcs. }\end{array}$ & $\begin{array}{c}\text { Quantity of bee colonies } \\
\text { on average in enterprise }\end{array}$ & $\begin{array}{c}\text { Productivity of one bee } \\
\text { colony, kg of honey/year }\end{array}$ \\
\hline Ukraine & 73.7 & 3.0 & & 24.7 \\
\hline the USA & 65.2 & 2.2 & 24.0 & 30.0 \\
\hline Argentina & 80.0 & 4.0 & 121.0 & 20.0 \\
\hline Russia & 53.5 & 3.9 & 9.6 & 18.4 \\
\hline Canada & 29.3 & 0.6 & 85.0 & 50.0 \\
\hline New Zealand & 10.5 & 0.4 & 130.0 & 27.8 \\
\hline Israel & 2.5 & 0.1 & 180.0 & 28.0 \\
\hline Spain & 30.4 & 2.4 & 98.0 & 12.6 \\
\hline
\end{tabular}

Source: [9; 10] 
transportation, storage, processing, sale of bee products, it should be noted that this contributes to the beekeeping enterprises competitiveness. Thus the main integrated indicator of the state of the company and which affects its strategic development is competitiveness. The concept of competitiveness is meaningful nowadays.

For example, M. Porter believes that competitiveness is conditioned by economic, social and political factors of the country situation or a particular commodity in the domestic and foreign markets [8]. B. Stephenson characterizes the competitiveness from the positions, "how effective the company meets customer needs in comparison with other companies offering similar goods or services" [8]. Ukrainian scientists consider competitiveness as the presence of the company's tangible and intangible opportunities and resources and conditions that ensure its sustainability in the long term [7]. Thus, competitiveness in domestic and foreign markets is characterized by the ability to deliver competitive products and the potential for such issues. However, competitiveness is an indicator, in which product competitiveness, industry, region and economy in general are revealed and intertwined.

Formation of methodological principles for determining beekeeping enterprises competitiveness takes place on the basis of features that are stipulated by the industry specificity. To specify the mechanism of formation of beekeeping enterprises competitiveness it is advisable to classify them according to the categories indicated in the definition (Figure 1).

Taking into account the level of factors influences on the competitiveness of beekeeping enterprise it is possible to highlight the following subsystems:

- external factors of competitiveness directly depends on the beekeeping enterprise opportunities to adjust its activities considering the influence of natural, economic, political, social, demographic, production and technological factors of the environment. The range of activities that can be offered in order to maintain an adequate level of external component include: effective lending and borrowing policy, fast rate of production process adaptation through innovative approaches in the management of the company to changing market conditions, development and modernization of its own resources;

- internal factors of competitiveness, are formed by making optimal management decisions to change production, information, labour, financial resources and social services. The range of measures in order to maintain an adequate level of internal component can offer tools motivational mechanism both moral and material incentives;

- sectoral economic stability, formed by a set of measures, based on the interest's integration of beekeeping enterprise with the agricultural enterprises. In this case, the level of beekeeping enterprise viability may be limited to only standard value selected for the integration of agricultural enterprise;

- ecological stability characterizes enterprise ability to maintain natural and economic balance and to improve environmental conditions of operations.

These beekeeping enterprises subsystems characterize different aspects of their development, and the level of influence on one another is high enough, and the result of their influence is the level of competitiveness. We can therefore say that the result of the overall competitiveness of the enterprise is based on the integrated operation of all subsystems [3].

Evaluation of the effectiveness of production technologies of bee products that determines the level of beekeeping enterprises competitiveness, connected with consideration of a number of factors that determine the nature of production resources use and market conditions of implementation. Small-sized private bee apiaries prevail in modern beekeeping of country, on which the development of scientific and technological progress and innovation are limited by manual

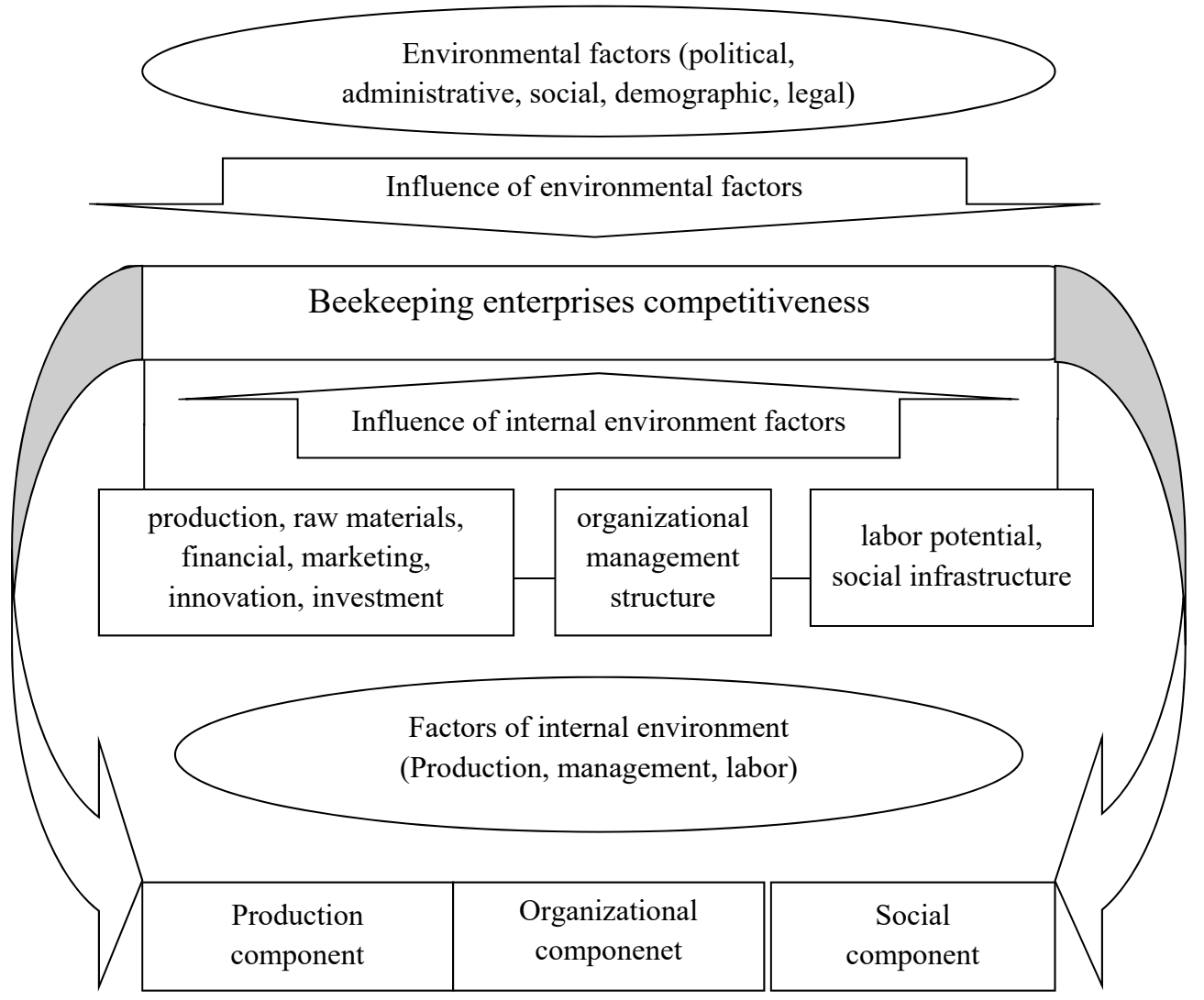

Figure 1. Factors of formation of beekeeping enterprises competitiveness 
labour prevalence, which low productive, and primitive means of production. Technologies for the most common bee products receiving can be substantially improved, taking into account national and international experience [6].

An integrated approach to evaluate the level of beekeeping enterprises competitiveness can be done with the help of comparative analysis of production efficiency on perspective apiaries of different sizes and organizational and legal forms of management. On the basis of the sample statistical indicators of four enterprises of Dnipropetrovsk region are examined: PAT "Bdzholoahroservis" of Solonianskyi district, FG "Bdzhilka" of Pavlohrad district, SFG "Medok" of Mahdalynivka district and PP "Sens" of Dnipropetrovsk region for 2011-2015 on average.

To calculate the efficiency of honey we have taken beekeeping enterprises different in size and technology of beekeeping. However, the production of honey in these farms is the basis for development of beekeeping enterprises, since only when bee colonies have sufficient quantity of honey they may have their full development and getting the majority of other bee products (Table 2).

The data in Table 2 indicate that PAT "Bdzholoahroservis" has the most effective honey production. FG "Bdzhilka" and SFG "Medok" have profitable honey production, but the profitability is low, $9.5 \%$ and $4.3 \%$ respectively, as in most beekeeping enterprises.

PP "Sens" has unprofitable production of honey and bee products as a whole for 2011-2015, which indicates the low quality of management decisions of the management, poor quality products, lack of effective distribution channels and high production costs.

The data of state statistical reports indicate that the economic efficiency of honey production of beekeeping enterprises has significant differences.

Perspective direction of honey and trade beekeeping development in the country is the creation of apiaries on a cooperative basis, the dimensions of which are determined by gross income. In modern beekeeping there are a lot of examples when within the horizontal (intrasectoral) cooperation private bee apiaries consolidate to share the expensive vehicles, mobile pavilions and equipment, conducting migration, protection and maintenance (handling, inspection, etc.) of bee colonies. An example of this association is beekeepers association of Kryvyi Rih "Travnevyi Sad".

Within vertical (intrasectoral) cooperation they carry out processing of honey, wax and other bee products, which is the feedstock for enterprises in other industries.

Theory and practice of beekeeping enterprises reforming demonstrate the need for the development of large commodity production based on cooperation and integration. This confirms the experience of foreign countries with developed beekeeping (the USA, Canada, Argentina, Mexico, Australia, Hungary, Romania, China, etc). There the private sector dominates over collective and state sectors. In average, it accounts $70-92 \%$ of bee colonies quantity and a significant part of production [5]

In order to enhance the competitiveness of beekeeping enterprises it is necessary to introduce the latest technology maintenance, migrations, bees swarming and obtaining products, establish primary processing of bee products, which will ensure maximum efficiency and their implementation, such as appropriate use of intensive beekeeping technology. The intensity in beekeeping is expressed as a rational bee maintaining. This means that throughout the season beekeeping enterprise are using methods that minimize the consumption of material resources and physical strength of beekeepers within guaranteed obtaining maximum impact products of bees labour.

This technology of intensive beekeeping does not require additional hives for bees. It is possible to receive a large quantity of real honey from 60 to $150 \mathrm{~kg}$ from one bee colony without increasing the number of bee colonies. Let us consider the economic calculation of this technology for PAT "Bdzholoahroservis" in Table 3.

Table 2

Economic efficiency of honey production in beekeeping enterprises of Dnipropetrovsk region, the average for 2011-2015

\begin{tabular}{|l|c|c|c|c|}
\hline \multicolumn{1}{|c|}{ Indicators } & $\begin{array}{c}\text { PAT } \\
\text { "Bdzholoahro- } \\
\text { servis" }\end{array}$ & FG "Bdzhilka" & SFG "Medok" & PP "Sens" \\
\hline Number of bee colonies, pcs. & 1036 & 436 & 112 & 66 \\
\hline Honey received from one bee colony, kg & 27.1 & 18.3 & 31.3 & 25 \\
\hline The price of 1 kg of honey, UAH. & 25.75 & 29.4 & 31.4 & 39.1 \\
\hline The level of effort for 1 kg of honey, person-hour & 2.1 & 2.4 & 3.1 & 3.9 \\
\hline The level of profitability (loss) of honey production, \% & 17.6 & 9.5 & 4.3 & -11.2 \\
\hline The level of profitability (loss) of beekeeping, \% & 28.9 & 14.3 & 8.4 & -4.5 \\
\hline
\end{tabular}

Economic efficiency of intensive beekeeping technology for PAT "Bdzholoahroservis"

\begin{tabular}{|l|c|c|c|}
\hline \multirow{2}{*}{\multicolumn{1}{|c|}{ Indicators }} & traditional & Technology & \multirow{2}{*}{ Changes, in \% } \\
\cline { 2 - 4 } & 1036 & 1036 & 100 \\
\hline Number of colonies, colonies & 28075.6 & 62160 & 2.2 times \\
\hline Gross yield of honey, kg & 27.1 & 60 & 2.2 times \\
\hline Honey performance of one bee colony, kg & 30.28 & 30.28 & 100 \\
\hline Price of 1 kg of honey, UAH & 850.1 & 1882.2 & 2.2 times \\
\hline Proceeds from sale of honey, ths. UAH & 722.9 & 1125.1 & 155.6 \\
\hline Total cost, ths. UAH & 25.75 & 18.10 & 70.3 \\
\hline Cost price of 1 kg of honey, UAH & 127.2 & 757.1 & 6.0 times. \\
\hline Profit (loss) - total, ths. UAH & 122.78 & 730.79 & 6.0 times \\
\hline For one bee colony, UAH & 17.6 & 67.3 & 49.7 g. p. \\
\hline Level of profitability, $\%$ & & & \\
\hline
\end{tabular}


Thus, as a result of use of this technology of intensive beekeeping it is possible to receive 62,160 tons of honey, and performance of one bee colony is $60 \mathrm{~kg}$ of honey. The cost of one $\mathrm{kg}$ of honey significantly reduced by $29.7 \%$ in comparison with traditional technology and will reach 18.10 UAH. As a result, this technology helps to receive 6.0 times more income than the traditional beekeeping as in a whole and in calculation per one bee colony. The level of profitability in the use of this technology will increase by $49.7 \mathrm{~g}$. p. in comparison with the traditional $67.3 \%$.

In general, the technology of intensive beekeeping is one of the most efficient, as it minimizes financial and physical costs while maximizing yields. It should be taken into account the most resistant to market relations models of organizational structures in beekeeping. In our opinion, there are three types of beekeeping enterprises and their apiaries that have increased competitiveness among the prospective enterprises. They accumulate the most salient positive trends in shaping the institutional mechanism of interaction through the production-processing and bee products realization.

Each of these production types is presented by the model farm (apiary), the most relevant to a certain level of management. Three levels of management have been distinguished while justification of medium-term prospects of beekeeping in the country. The first one involves the most promising model of bee apiary that has optimal size and structure of production, providing its owners a competitive, self-sufficient development in market conditions. It is located in the administrative district to obtain guaranteed volumes of products, pollinating crops by bees and saturation of the local market with beekeeping products.

The size bee apiary (100-150 bee colonies) provides the most efficient use of employees throughout the calendar year - beekeepers and their assistant and use of modern means of mechanization.

The second one is presented as a model bee farm that takes advantage of high-tech manufacturing. The peculiarity of the institutional mechanism of this type of production is the ability to combine production, primary processing of products, raw materials and marketing activities into a single unit. It is assumed that bees and beekeeping products model farm will be implemented independently both in rural and regional markets as part of procurement and trade organizations involved in inter-regional market. Bee farms can be successfully used for pollinating large volumes of entomophile crops on crop farms, and act independently with their products as a relatively large commodity production in the region. In the future, a limited number of such bee farms can effectively use the resources of individual district.

The third one is represented by a model integrated system, which includes the parent company and the network of bee apiaries of different sizes and organizational and legal types of management, as well as enterprises and organizations of agricultural sector of economy and other sectors of the economy, interested in joint activities of production, processing and realization of bee products. Geographically, this system can combine beekeeping area, region, and in the future be a representative of interregional organizations and act independently on the international market.

It is necessary to match internal organizational and economic measures for the development of market relations in beekeeping with international requirements in order Ukraine could participate in the international agricultural market with beekeeping enterprises products. This is due to the increased role of the state as guarantor enterprises out of the crisis and creating conditions for sustainable further development [4].
In terms of market relations, the importance of the principle of rational distribution and combining the regions specializations in the production of certain products for export as well as for the purpose of self-sufficiency. The last ensure cooperation.

The importance and urgency of cooperation id discussed in a special UNO General Assembly resolution 56/114 "Cooperatives in social development" dated June 18, 2002. According to the experience of some countries, service cooperatives are creating to reduce the number of intermediaries and improve the process of bee products promotion from producer to final consumer.

One of the most important prerequisites of such service cooperatives is territorial concentration of beekeeping enterprises, their interest in establishing cooperative structures. These service cooperatives combine only part of the assets of beekeeping enterprises necessary for normal functioning of the cooperative by transferring to it the property contribution from fixed positions in the constituent agreement on cooperative creation.

The advantages of such cooperatives creation for beekeeping enterprises are:

- taking part in a large volume production, creating competition for intermediaries and avoid competition within the cooperation, using professional managerial staff;

- receiving profit except production and from subsequent advancement stages of produced bee products;

- possibility of entering the markets, supplies and services, including international markets;

- benefits of coordination in the cooperative association, share risk and provide appropriate control on the market [6].

It is through cooperation beekeeping enterprises can properly form an appropriate system of bee products promotion and opportunity to get a real price for these products both on the domestic and foreign markets.

Beekeeping integration of different areas involves the formation of financial and material resources of enterprises, the creation of highly mechanized large apiaries. It is possible to have a direct connection according to the scheme: bee apiary - processing - product realization.

Horizontal integration (intrasectoral) is generally effective in cooperative groups. Within this type of integration, the issues of financial mutual aid and lending, training and retraining, when highly-qualified beekeepers teach students beekeeping through joint work on an apiary, are successfully resolved.

Interregional integration is the acquisition of land integrator of beekeeping land, bee hives and beekeeping resources of the enterprise (agricultural enterprises) in different regions. The principles of voluntariness, democratic centralism, territorial, sectoral, functional and others should be taken into account. Mutual cooperation should provide production growth of bee products and income, solving social problems of the village.

Forming of integration links between service cooperatives and credit unions is also perspective. These structures cooperate in overcoming the shortage of financial resources for the development of service cooperatives, which in turn will provide the necessary funds and turnover will affect the efficiency of production processes in beekeeping enterprises, facilitate development of new sources of investment of beekeeping products.

Conclusions. Improving the competitiveness of beekeeping enterprises in the future should be made by: association of beekeeping enterprises based on cooperation and the use of integrated systems towards a highly mechanized large bee apiaries; integration of credit unions; maintenance of production based on modern technologies and innovative part 
in the formation of financial and material resources according to the scheme: production - processing -realization. Such cooperation of all members of the marketing chain should provide production growth of bee products and income, overcoming the lack of financial resources for the development of service cooperatives, which in turn will provide the necessary circulation of funds and affect the efficiency of production processes in beekeeping enterprises, facilitate the formation of new investment sources of production development of beekeeping products.

1. Akmaiev A.I. (2007) Udoskonalennia otsinky konkurentospromozhnosti pidpryiemstva $\mathrm{v}$ umovakh hlobalizatsii [Improving the assessment of the competitiveness of the enterprise in the context of globalization]. Kultura narodov Prychernomoria, vol. 99, pp. 7-10.

2. Aleksandrova O.V. (2012) Ekonomichna stiikist silskohospodarskoho vyrobnytstva yak osnovnyi chynnyk yoho konkurentospromozhnosti [Economic stability of agricultural production as a major factor in its competitiveness]. Zbirnyk naukovykh prats Tavriiskoho derzhavnoho ahrotekhnolohichnoho universytetu, no. 2, t. 3, pp. 13-21.

3. Alekseenko N.V. (2008) Ustoichivoe razvitie predpriiatiia kak faktor ekonomicheskogo rosta [Sustainable development of the enterprise as a factor of economic growth]. Ekonomika i organizatciia upravleniia: zb. nauk. pr, no. 3, pp. 59-65.

4. Buhai V.Z., Omelchenko V.M. (2008) Analiz ta otsinka finansovoi stiikosti pidpryiemstva [Analysis and assessment of the financial stability of the enterprise]. Derzhava ta rehiony, no. 1, pp. 34-39.

5. Buhera S.I. (2009) Promyslove bdzhilnytstvo: orhanizatsiino-pravovyi aspect [Industrial beekeeping: organizational and legal aspect]. Pasika, no. 4, pp. 2-3.

6. Vasylchak S.V. (2015) Ekonomichna stiikist silskohospodarskykh pidpryiemstv: stratehichnyi menedzhment [Economic sustainability of agricultural enterprises: strategic management]. Zb. nauk. prats "Formuvannia rynkovykh vidnosyn v Ukraini" [za red. I.H. Mansurova], vol. 6 (169), pp. 67-70.

7. Melnyk S.I. (2010) Osnovni napriamky formuvannia konkurentnykh perevah ahrarnykh pidpryiemstv Ukrainy v rynkovykh umovakh: monohrafiia [The main directions of formation of competitive advantages of agrarian enterprises of Ukraine in market conditions: monograph]. Luhansk: Noulidzh (in Ukrainian)

\section{Список використаних джерел:}

1. Акмаєв А.І., Коваленко Н.В. Удосконалення оцінки конкурентоспроможності підприємства в умовах глобалізації. Культура народов Причерноморья. 2007. Вип. 99. С. 7-10.

2. Александрова О.В. Економічна стійкість сільськогосподарського виробництва як основний чинник його конкурентоспроможності. Збірник наукових праџь Таврійського державного агротехнологічного університету. 2012. № 2. Т. 3. С. 13-21.

3. Алексеенко Н.В. Устойчивое развитие предприятия как фактор экономического роста. Економіка і організація управління: зб. наук. пр. 2008. № 3. С. 59-65.

4. Бугай В.З., Омельченко В.М. Аналіз та оцінка фінансової стійкості підприємства. Держава та регіони. 2008. № 1. С. 34-39

5. Бугера С.І. Промислове бджільництво: організаційно-правовий аспект. Пасіка. 2009. № 4. С. $2-3$.

6. Васильчак С.В. Економічна стійкість сільськогосподарських підприємств: стратегічний менеджмент. Формування ринкових відносин в Україні / за ред. І.Г. Мансурова. Київ, 2015. Вид. 6 (169). С. 67-70.

7. Мельник C.I. Основні напрямки формування конкурентних переваг аграрних підприємств України в ринкових умовах: монографія. Луганск : Ноулідж, 2010. 368 с.

\section{ОРГАНІЗАЦІЙНО-ЕКОНОМІЧНІ ЗАХОДИ ЩОДО ПІДВИЩЕННЯ РІВНЯ УПРАВЛІННЯ ЕКОНОМІЧНОЮ СТІЙКІСТЮ ТА ЕФЕКТИВНІСТЮ ПІДРИСМСТВ ОРГАНІЧНОГО ТВАРИННИЦТВА В АГРАРНОМУ СЕКТОРІ}

Анотація. У статті висвітлені теоретичні засади з організації економічних заходів щодо підвищення рівня управління економічною стійкістю та ефективністю підприємств органічного бджільництва в аграрному секторі. Сформовано організаційний механізм взаємодії по лінії «виробництво-переробка» $з$ виділенням трьох типів модельних підприємств. Обгрунтовано об'єднання підприємств бджільництва на основі кооперації та з використанням інтегрованих систем в напрямку створення високомеханізованих великих бджоло пасік. Основними економічними, організаційними та технологічними пріоритетами конкурентоспроможного виробництва бджіл, характерними для аграрного сектору, $\epsilon$ вдосконалення технології виробництва підприємств бджільництва. Втрати у бджільництві за роки реформ пов'язані 3 ліквідацією більшості спеціалізованих господарств з виробництва бджільництва меду та торгівлі та частково внесення добрив, незадовільним станом більшості ферм, що залишились, розпадом міжгосподарських бджільницьких об’ єднань, а також великих пасік та бджільницьких ферм, різким падіння приладів та обладнання для бджільництва, послаблення агрозооветеринарної служби пасік через брак належного фінансування тощо. Це відкриває перспективи для розвитку бджільницьких підприємств України. Ключовими питаннями на майбутнє є впровадження сучасних технологій на підприємствах бджільництва та виробництво чистих продуктів бджільництва, безпека лікарських засобів, які вони виробляють для боротьби із хворобами бджіл, належне використання хімічного захисту медоносних рослин, відповідне оновлення інструментів та обладнання бджіл, ефективне використання робочої сили, земельних та фінансових ресурсів та розробка програмного забезпечення інформаційної інфраструктури. Дослідження продуктивних сил бджільницьких підприємств слід проводити з метою ефективного використання предметів та засобів праці. Цей ефект обумовлений пізнанням об’єктивних та суб'єктивних законів розвитку продуктивних сил, законів та принципів їх функціонування. Продуктивні сили підприємств бджільництва перебувають у постійному русі, змінюючи його якісний статус і впливаючи на рівень економічної стабільності окремого підприємства. Це слід враховувати під час їх досліджень та обгрунтування напрямків вдосконалення.

Ключові слова: економічна стійкість, підприємства бджільництва, модельні підприємства, інтегровані системи, аграрний сектор. 


\section{ОРГАНИЗАЦИОННО-ЭКОНОМИЧЕСКИЕ МЕРОПРИЯТИЯ ПО ПОВЫШЕНИЮ УРОВНЯ УПРАВЛЕНИЯ ЭКОНОМИЧЕСКОЙ УСТОЙЧИВОСТЬЮ И ЭФФЕКТИВНОСТЬЮ ПРЕДПРИЯТИЙ ОРГАНИЧЕСКОГО ЖИВОТНОВОДСТВА В АГРАРНОМ СЕКТОРЕ}

Аннотация. В статье освещенные теоретические принципы по организации экономических мероприятий относительно повышения уровня управления экономической стойкостью и эффективностью предприятий органического пчеловодства в аграрном секторе. Сформирован организационный механизм взаимодействия по линии “производствопереработка" с выделением трех типов модельных предприятий. Обосновано объединение предприятий пчеловодства на основе кооперации и с использованием интегрированных систем в направлении создания высокомеханизированных больших пчелопасек. Сформирован организационный механизм взаимодействия по линии «производство-переработка» с выделением трех типов модельных предприятий. Обоснованно объединения предприятий пчеловодства на основе кооперации и с использованием интегрированных систем в направлении создания высокомеханизированных крупных пасек.

Ключевые слова: экономическая стойкость, предприятия пчеловодства, модельные предприятия, интегрированные системы, аграрный сектор. 